\title{
An Improved Grid Connected PV Generation Inverter Control System and Analysis of \% THD for Inverter
}

\author{
Govind Poonia ${ }^{1}$, SSPM Sharma B ${ }^{2}$ \\ Integrated M.Tech. Scholar, Mewar University, Chittorgarh, Rajasthan, India \\ Assistant Professor, Department of electrical Engineering Mewar University, Chittorgarh, Rajasthan, India
}

\begin{abstract}
In this paper we study the operational principle and the structure of the grid-connected photovoltaic system inverter control system and analysis of \% THD for inverter with filter and without filter. Mainly the two inverter control methods. 1) voltage source inverter control method 2) power type PWM inverter control method.

On the basis of above two kinds of inverter control methods, we will present an improved PWM inverter control system that can be applied in grid-connected PV generation and uses MATLAB/Simulink software to simulate and analyze. The result of the simulation shows that the improved inverter control system can effectively control the grid current waveform which tends to sine wave, means while it can achieve the maximum power point tracking, besides it is able to put the arbitrary power out to the load or to the grid, while the control system has a good stability. It also shows that as the increasing number of inductive load penetrate the grid, the load waveform distortion is produced, but it will not affect the reliability of power supply.

In this paper, we study also the different types of inverter were designed by using MATLAB / SIMULINK and $\%$ THD (Total harmonics distortion) was compared.
\end{abstract}

\section{Introduction}

At present, large scale photovoltaic power generation and scale of renewable energy has become parts of development strategy, meanwhile it is the way to guide the development of photovoltaic industry. Grid connected photovoltaic power systems are power system energized by photovoltaic panels which are connected to the utility grid. Grid connected power systems comprise of PV panels

MPPT - maximum power point tracking, Solar inverters ,Power conditioning units ,Grid connection equipments - Here two inverter control methods are describe-1) Voltage source inverter control method 2) Power type PWM inverter control method.

\section{Grid Connected Pv Generation System}

Grid connected PV generation system is mainly composed of the PV array, the inverter device with the function of maximum power tracking and the control system. Photovoltaic system use solar panels to convert sunlight into electricity. A system is made up of one or more solar PV panels, an AC or DC power converter that holds the solar panels, and the interconnections and mounting for the other components.

Photovoltaic modules or solar panels:- A photovoltaic array is a linked assembly of PV modules. Most PV array use an inverter to convert the dc power produced by the modules into alternating current. The modules in a PV array are connected in series to obtain the desired the voltage, the individual string are then connected in parallel to allow the system to produce more current.

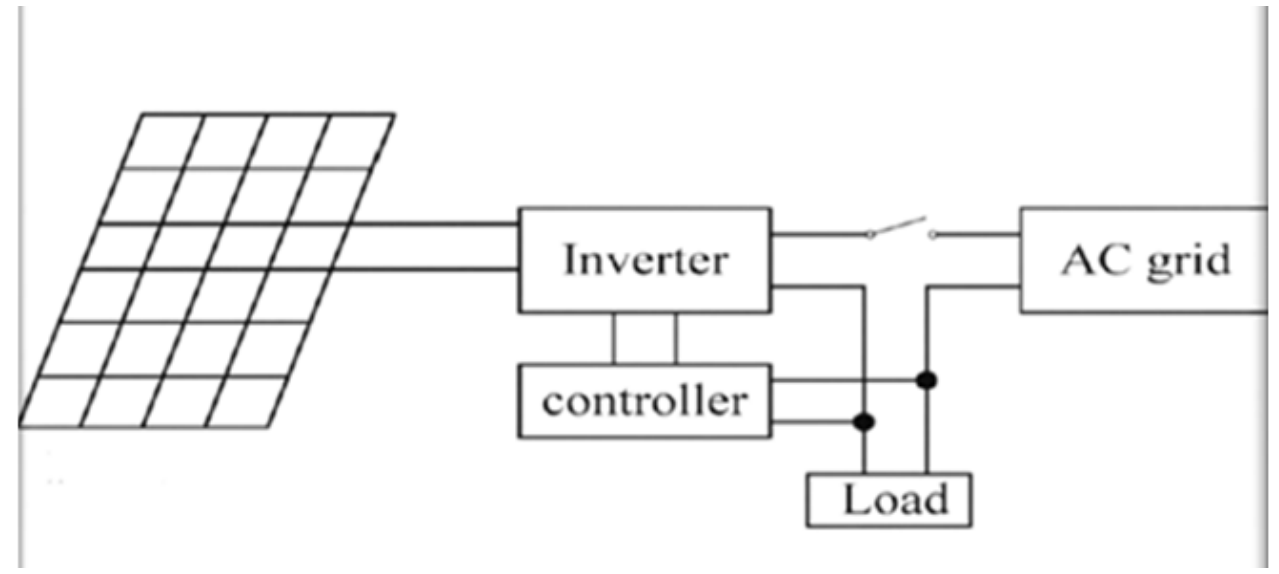

Fig:2.1 grid connected PV power structure 
2.1Maximum power point tracking:- Solar inverters use maximum power point tracking to get the maximum possible power from PV array. Solar cells have a complex relationship between solar irradiation, temperature and total resistance that produces a non-linear output efficiency known as the I-V curve. It is the purpose of a MPPT system to sample the output of the cells and determine a resistance to obtain maximum power for any given environmental conditions.

\subsection{Characteristics of solar array:-}

1) Photovoltaic cell

2) Photovoltaic module

3) Photovoltaic array

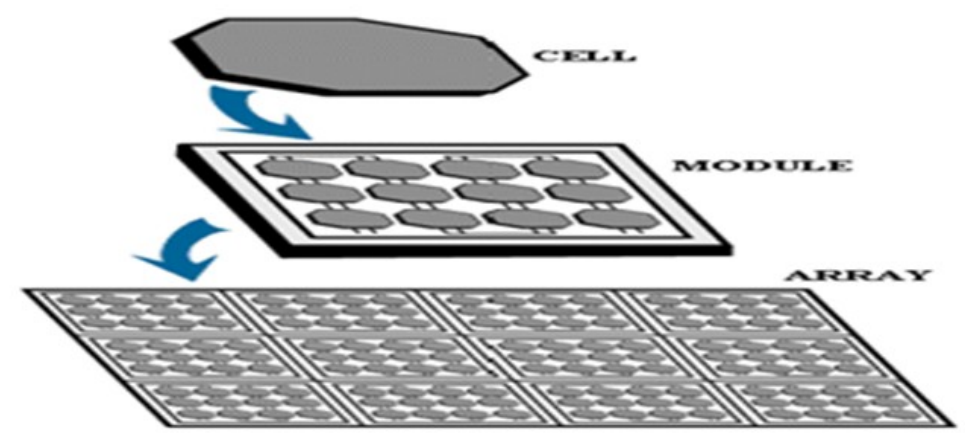

Fig 2.2 Photovoltaic Hierarchy

\subsection{Working of PV cell:-}

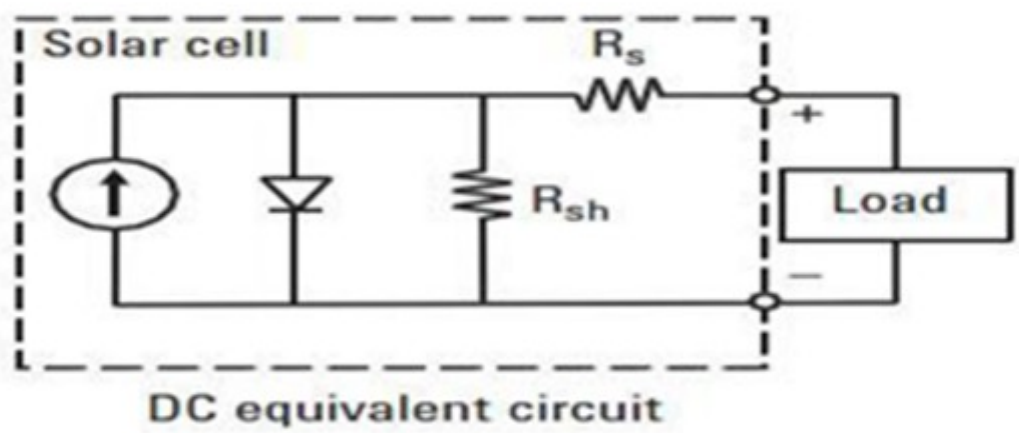

Fig 2.3 DC Equivalent Circuit

$$
\mathrm{V}_{\mathrm{C}}=\left(\mathrm{A} * \mathrm{~K}^{*} \mathrm{TC} / \mathrm{e}\right) \ln [(\mathrm{Iph}+\mathrm{I} 0-\mathrm{IC} / \mathrm{I} 0)-\mathrm{RS} * \mathrm{IC}
$$

$\mathrm{V}_{\mathrm{C}}=$ cell output voltage

$\mathrm{T}_{\mathrm{C}}=$ reference cell operating temperature

$\mathrm{R}_{\mathrm{S}}=$ series resistance of cell

$\mathrm{I}_{\mathrm{Ph}}=$ photocurrent, function of irradiation level and junction temperature

$\mathrm{I}_{0}=$ reverse saturation current of the diode

$\mathrm{I}_{\mathrm{C}}=$ cell output current

$\mathrm{K}=$ Boltzmann constant $(1.38 * 10-23 \mathrm{j} / \mathrm{k})$

$\mathrm{e}=$ electron charge $(1.602 * 10-19 \mathrm{c})$ 
III. Analysis Of \% THD For Inverter

3.1 Analysis Of \% Thd For Different Inverter (Without Filter) :-

A. Single phase full bridge inverter-

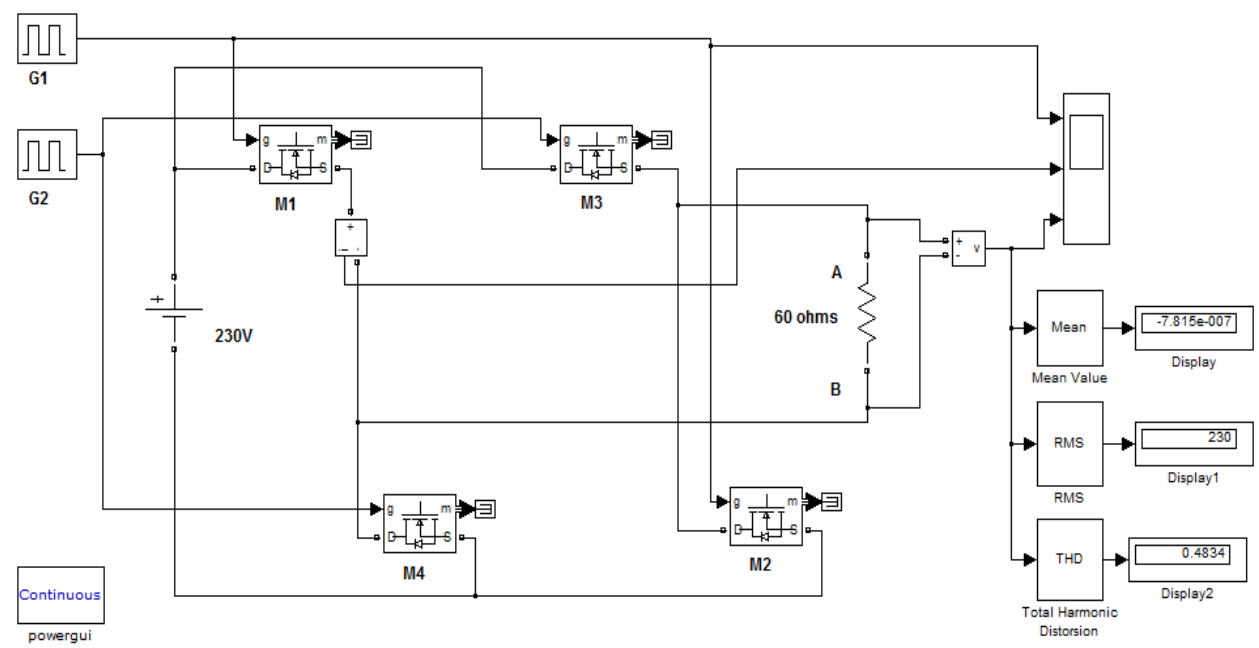

Simulink model of Single phase full bridge inverter-

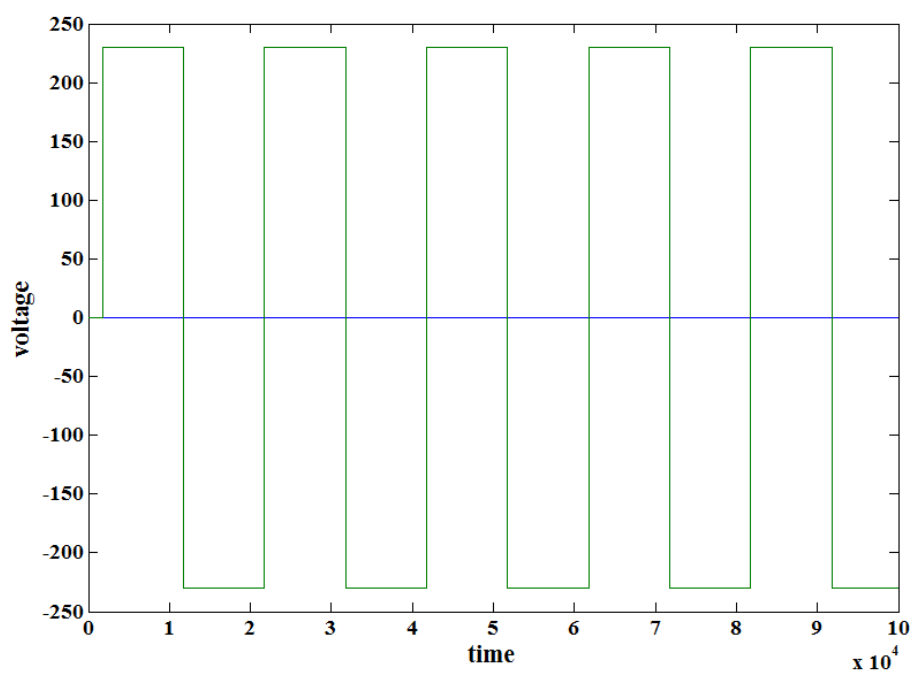

Fig 3.1 output voltage waveform

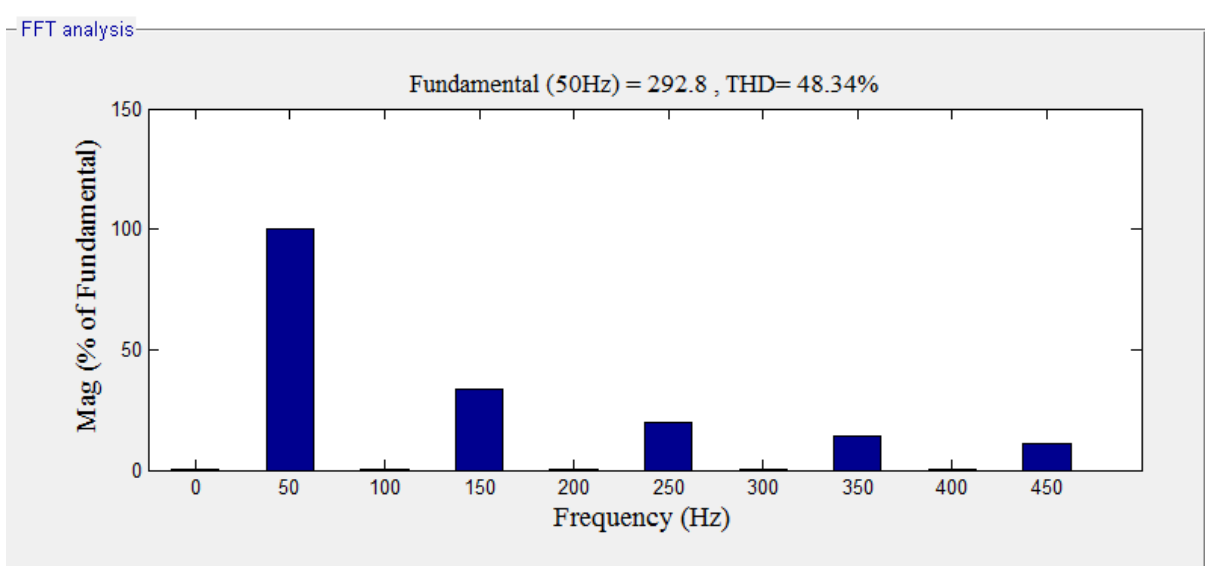

Fig.3.2 FFT analysis of output voltage 
B. Three phase full bridge inverter (120. Mode):-

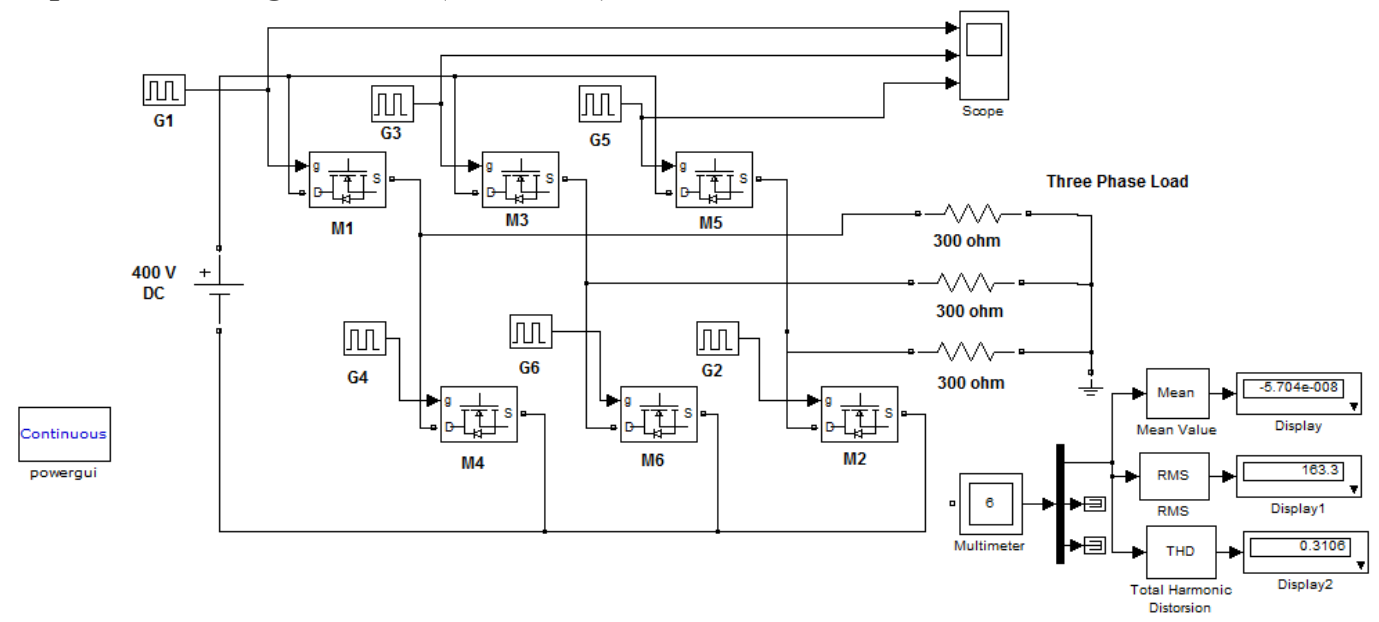

Simulink model of Three phase full bridge inverter (120. Mode):

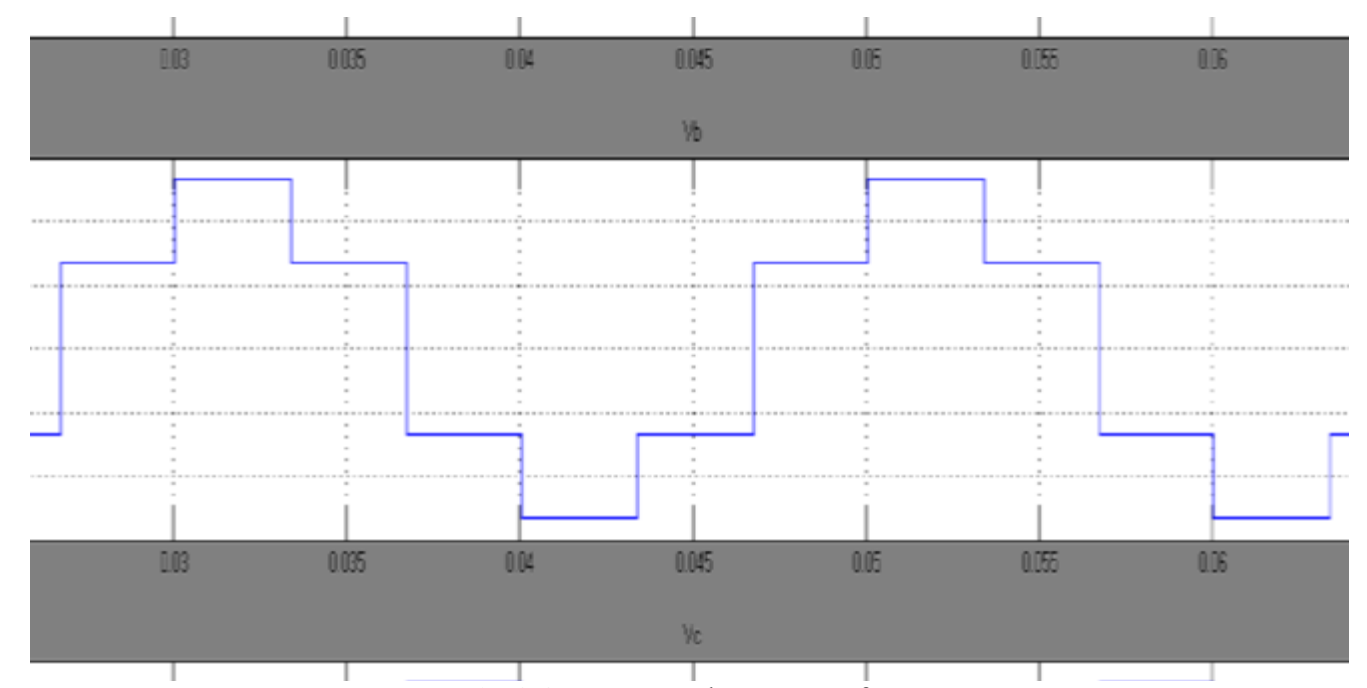

Fig.3.3 output voltage waveform

Fundamental $(50 \mathrm{~Hz})=255, \mathrm{THD}=31.06 \%$

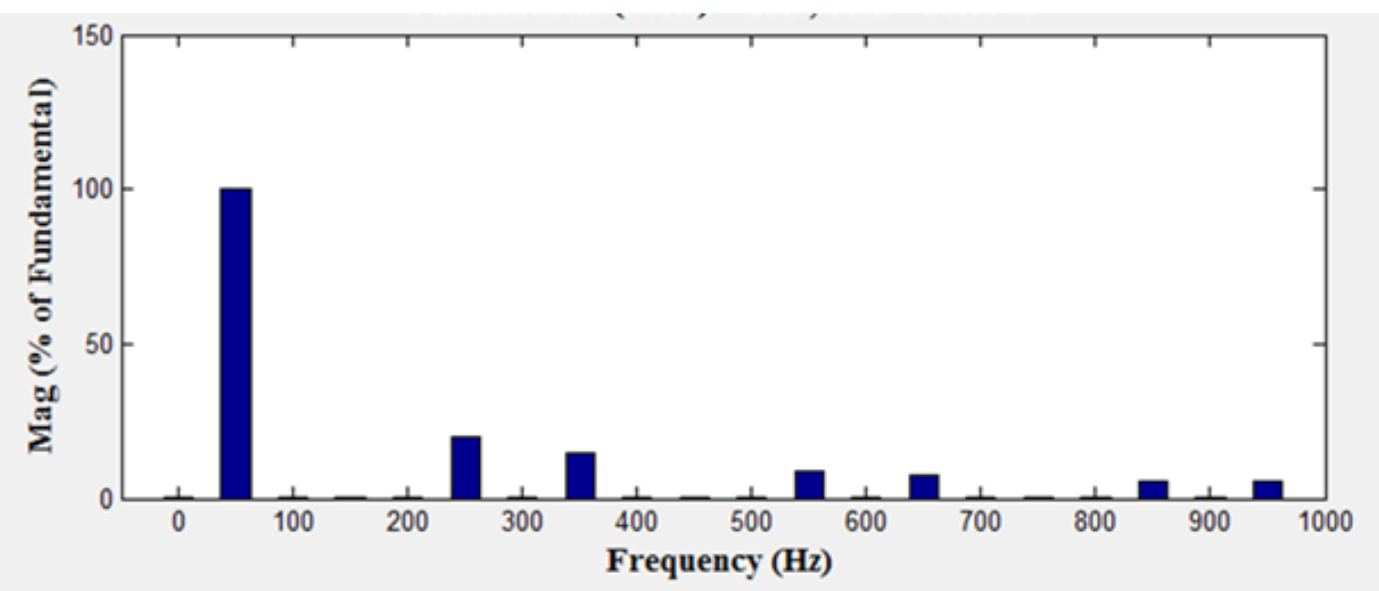

Fig.3.4 FFT analysis of output voltage 
B.1. Three phase inverter (180. Mode):-

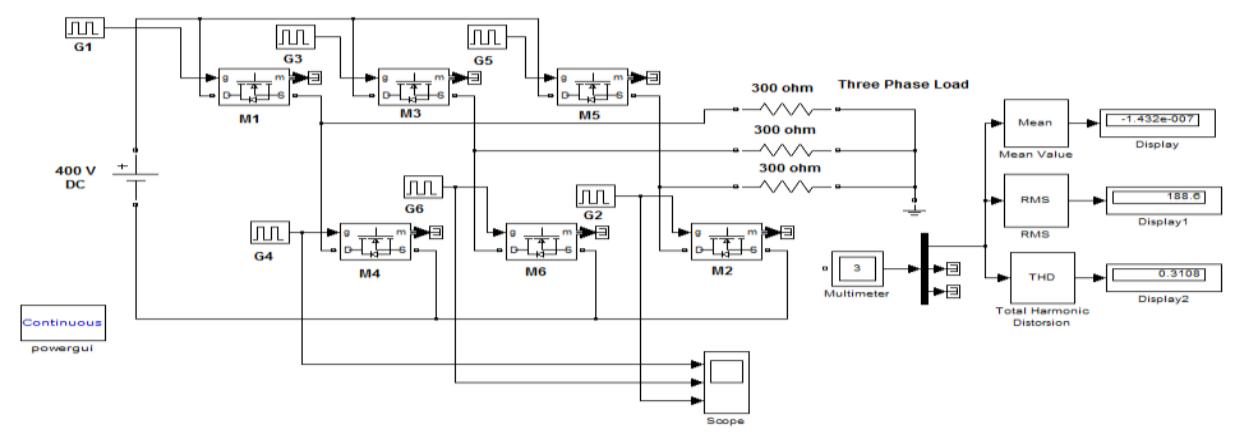

Simulink model of Three phase inverter (180. Mode

Fundamental $(50 \mathrm{~Hz})=246.3, \mathrm{THD}=31.08 \%$

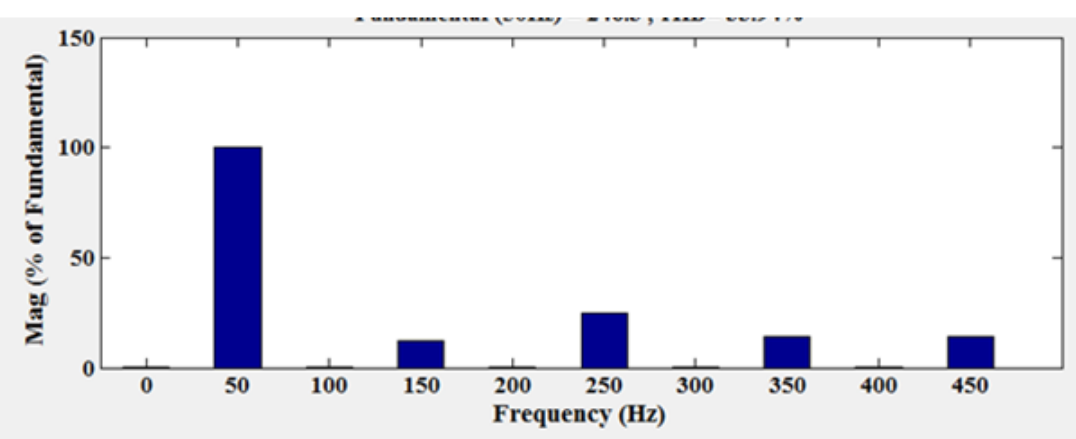

Fig.3.5 FFT analysis of output voltage

C. Single phase full bridge inverter with filter:-

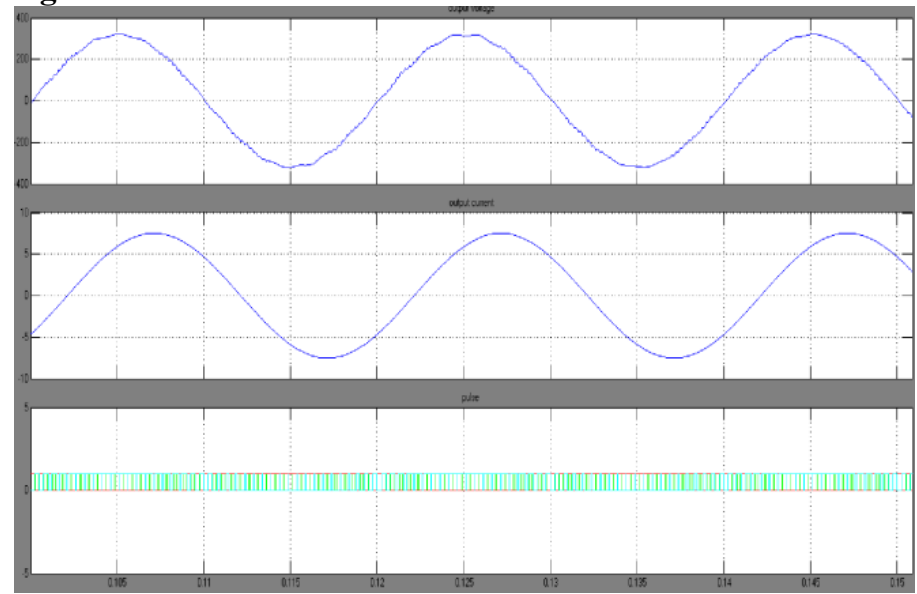

Fig.3.6 output voltage and current waveform

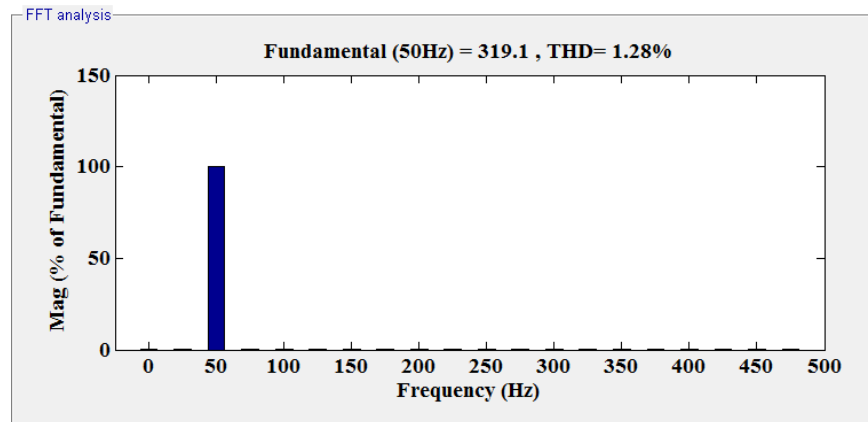

Fig.3.7 FFT analysis of output voltage 
(d) Three phase full bridge inverter with filter:-

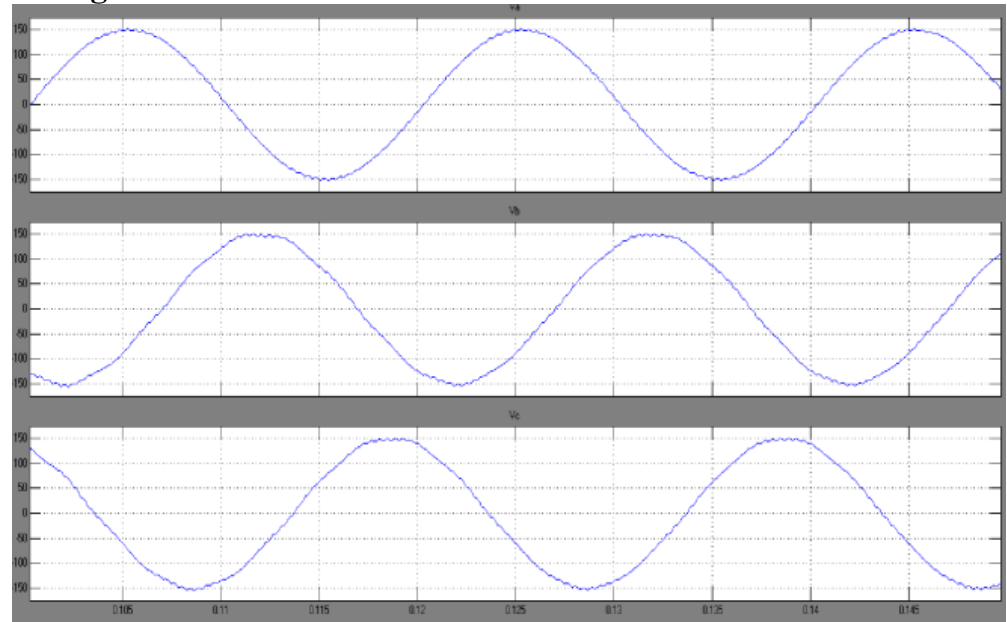

Fig.3.8 output voltage waveform

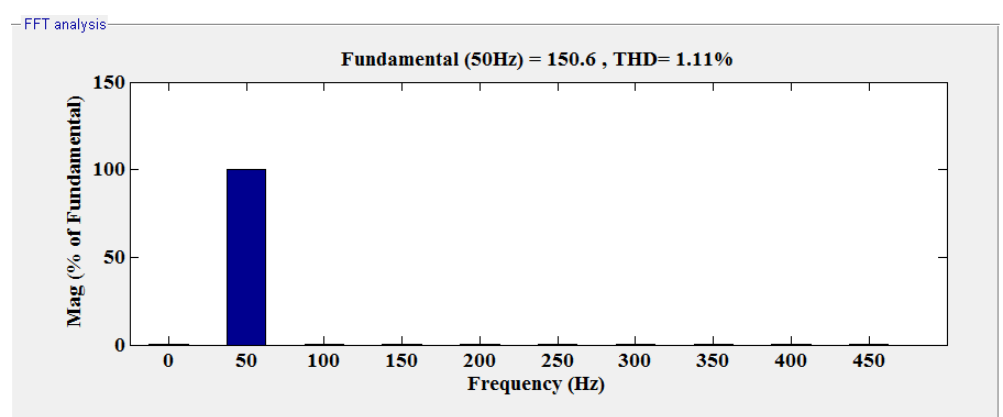

Fig.3.9 FFT analysis of output voltage

Table I Analysis Of \%THD For Different Inverter (Without Filter)

\begin{tabular}{|c|c|c|c|c|}
\hline \multirow{2}{*}{ S.No } & Parameter & \multicolumn{3}{|c|}{ Types of Inverter } \\
\cline { 3 - 5 } & & $\mathbf{1}$ & \multicolumn{2}{|c|}{$\mathbf{3 \phi}$} \\
\cline { 3 - 5 } & & & $\mathbf{1 2 0}$ Mode & $\mathbf{1 8 0}$ Mode \\
\hline 1. & Input voltage & 230 & 400 & 400 \\
\hline 2. & & $1 \mathrm{KW}$ & $1 \mathrm{KW}$ & $1 \mathrm{KW}$ \\
\hline 3. & P wer & & & 0.8 \\
\hline 4. & Power factor & & 0.8 & $31.08 \%$ \\
\hline
\end{tabular}

Table II Analysis Of \%THD For Different Inverter (With Filter)

\begin{tabular}{|c|c|c|c|}
\hline \multirow[t]{2}{*}{ S.No } & \multirow[t]{2}{*}{ Parameter } & \multicolumn{2}{|c|}{ Types of Inverter } \\
\hline & & $1 \phi$ & $3 \phi$ \\
\hline 1. & Input voltage & 230 & 326 \\
\hline 2. & Power & $1 \mathrm{KW}$ & $1 \mathrm{KW}$ \\
\hline 3. & Power factor & 0.8 & 0.8 \\
\hline 4. & Switching frequency & $2 \mathrm{KHz}$ & $2 \mathrm{KHz}$ \\
\hline 5. & Modulation Index & 1 & 1 \\
\hline 6. & \%THD & $1.28 \%$ & $1.11 \%$ \\
\hline
\end{tabular}

\section{Inverter Control Theory}

\subsection{Voltage source inverter control method}

The pv array working voltage is set to $\mathrm{Ed}$, the standard voltage $\mathrm{E}_{\mathrm{dr}}$ should be matched with the working voltage when the pv array is in the maximum power output state. The standard current $\mathrm{I}_{\mathrm{br}}$ should be kept to 
sinusoidal while the power factor should be kept to one which can be realized by PWM control method. $\mathrm{S}_{\mathrm{w}}$ is a switch which mainly protects the inverter and cuts the inverter from the system when the system power is off.

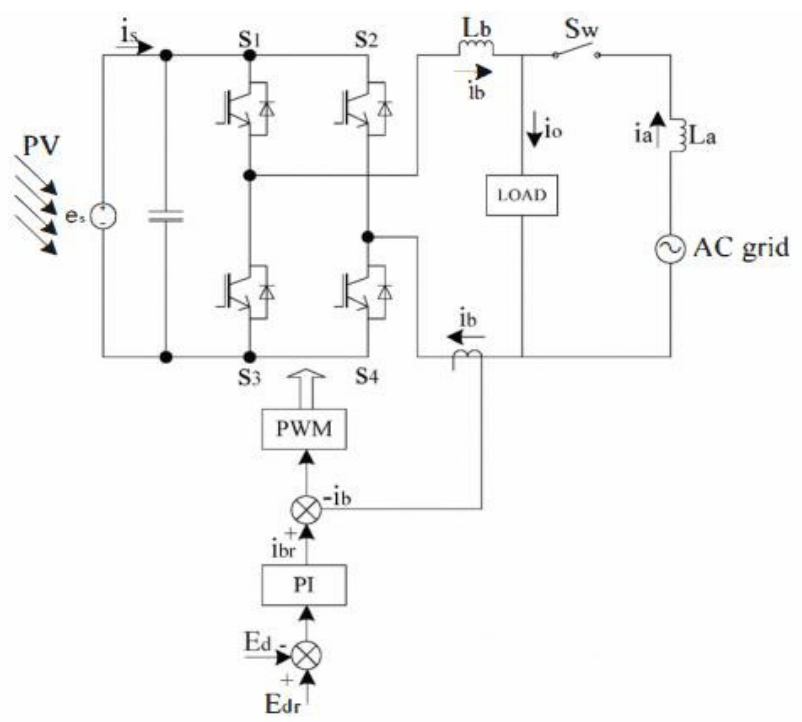

4.1 Voltage source inverter with control method

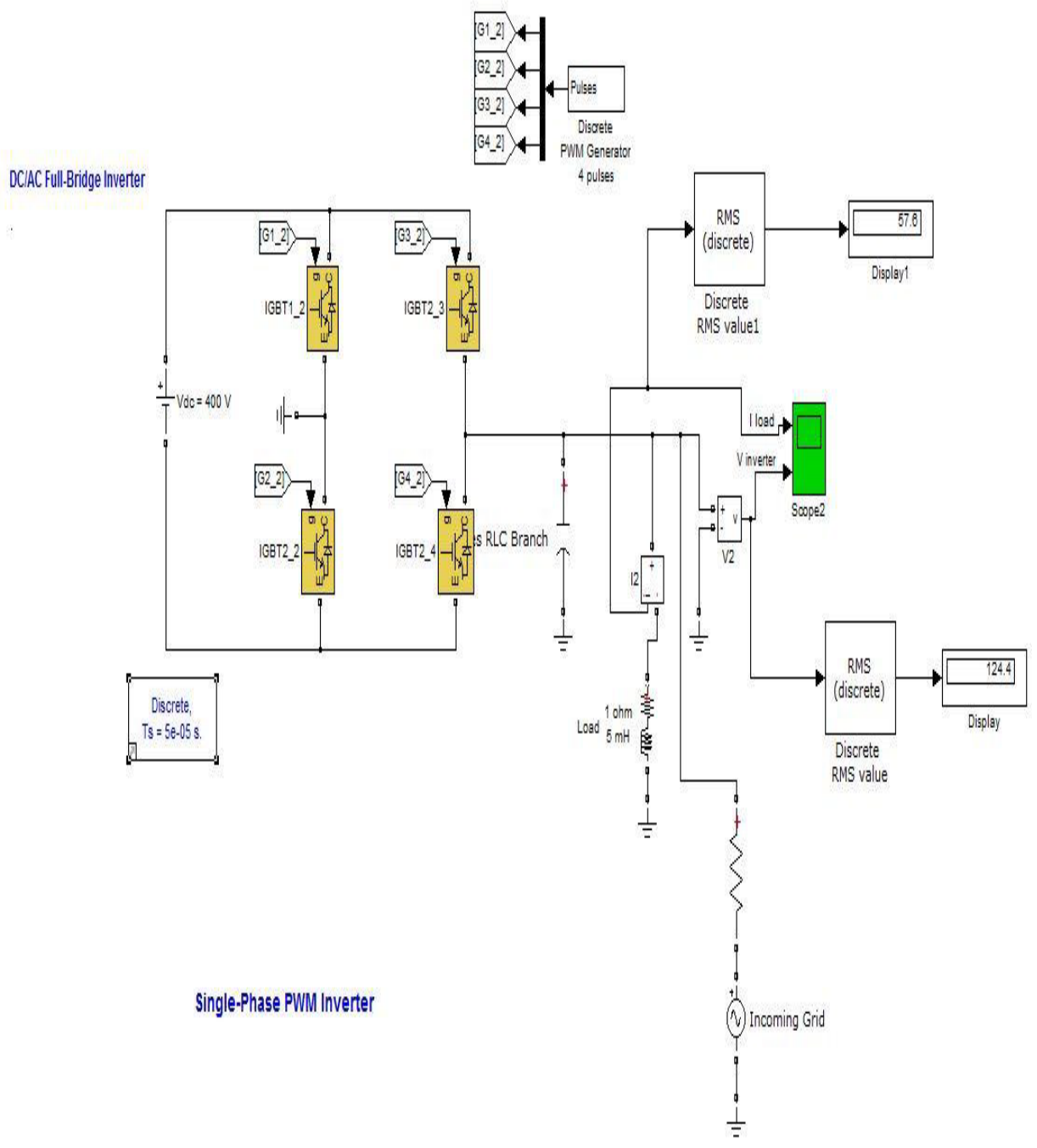




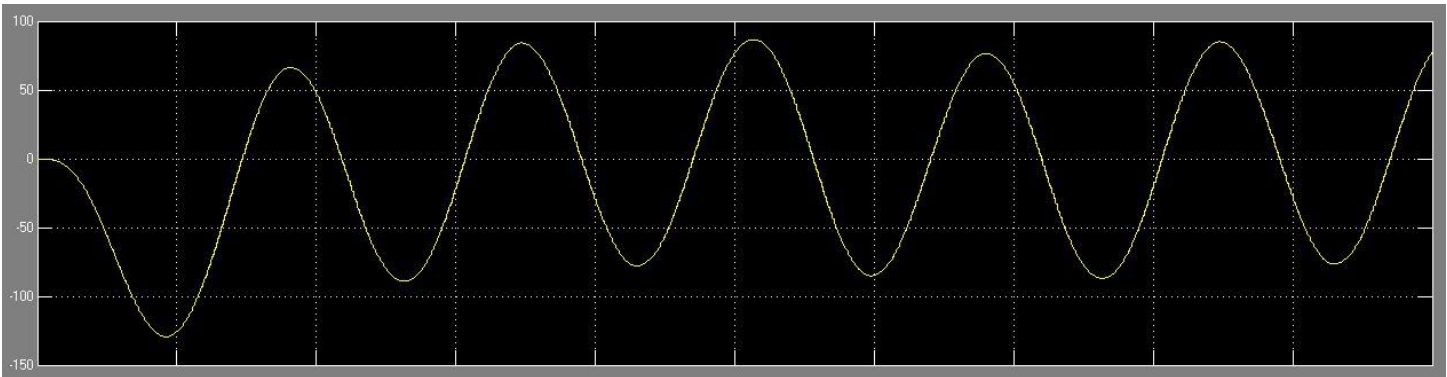

current waveform

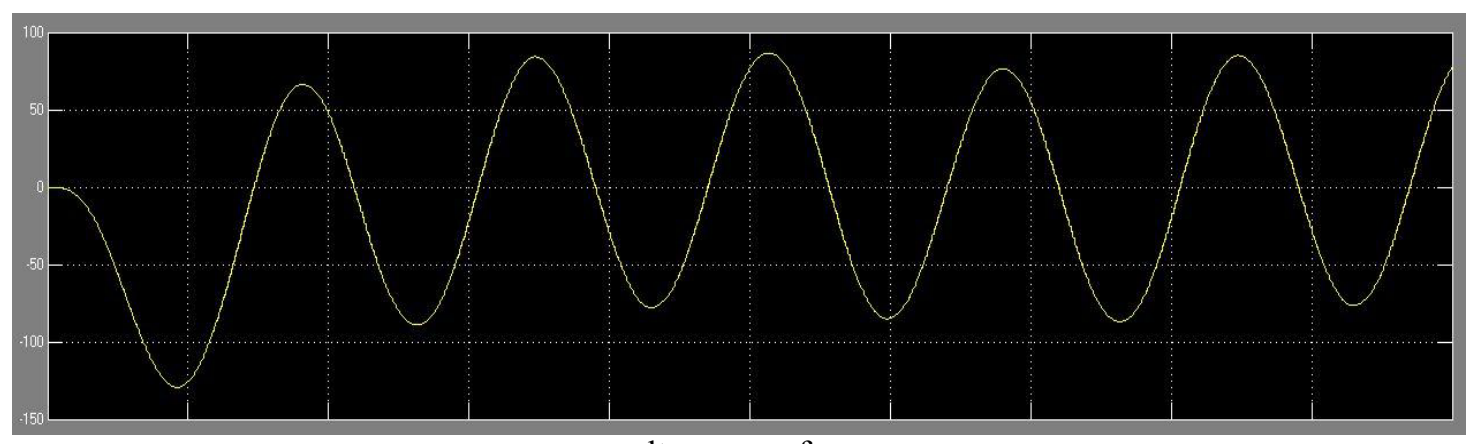

voltage waveform

\subsubsection{Power type PWM inverter control method}
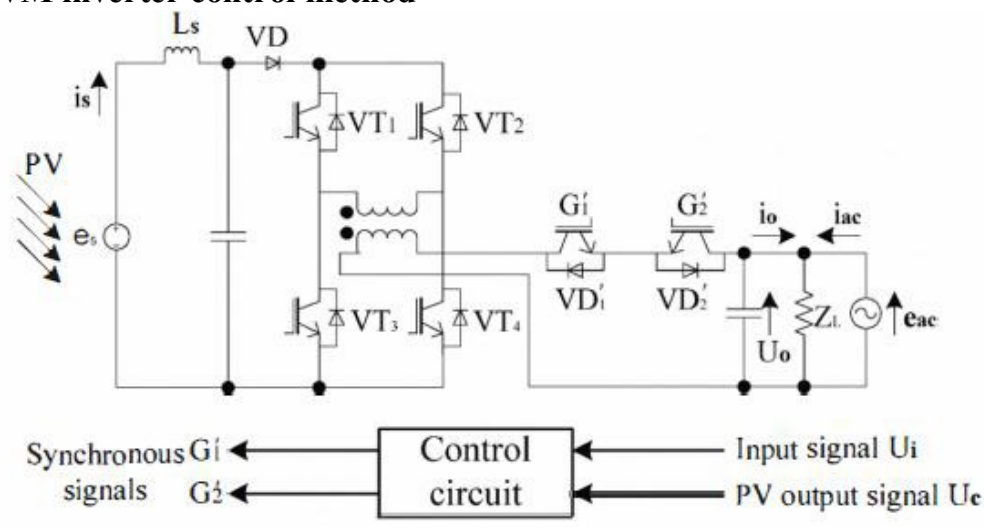

4.2 Power type PWM inverter control system

4.3

4.1.3 Improved PWM inverter control method

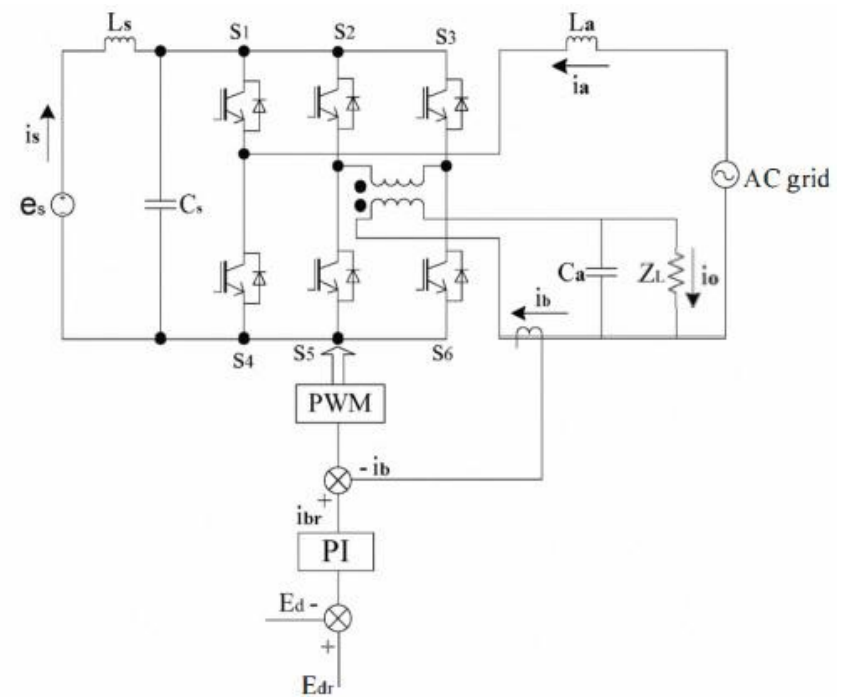

4.3 Improved type PWM inverter control system 
The control system is composed of three parts which are AC voltage control, DC voltage control and phase angle control. As to the AC voltage control part, let's set the AC output voltage to Eo, and its standard voltage is $\mathrm{E}_{\mathrm{or}}$, this signal reflect the phase of source voltage, directly impact power transmission between $\mathrm{AC}$ grid and DC system. Additionally, it should add a control signal

which maintains a certain DC voltage. Based on the two signals, sine function generator produces the AC control standard voltage. Inside of the voltage control loop contains current control loop which it is not directly impact the result of voltage control. In actually fact, the PV output current is not the same with DC source. Because this current contains the high frequency component including output of active filters, time constant of current regulator should not choose too large.

The relationship among operating angular frequency $\omega$, standard frequency $\omega$ o and slip angular frequency $\Delta \omega$ is shown here.

$$
\omega=\omega 0+\Delta \omega
$$

$\Delta \omega$ can also be calculated through determining power deviation, the equation is shown

$$
\Delta \omega=\mathrm{K}_{\mathrm{p}}\left(\mathrm{E}_{\mathrm{dr}}-\mathrm{E}_{\mathrm{d}}\right)
$$

If $\Delta \omega$ is too large, the control system may be unstable, so saturation circuit should be set to restrict $\Delta \omega$ to change too large.

\section{Conclusion}

Improved PWM inverter control system is based on the voltage type control method and the PWM power type control method. The result of simulation and conclusions shows that the improved PWM inverter control method can make the voltage and the current waveform of the grid tend to sine wave effectively and quickly, and the power factor will reach to one. The power can be sent to the grid or load arbitrary through controlling the PWM regulator, while the control system has a good stability. It also shows that as the increasing number of inductive load penetrate the grid, the load waveform distortion is produced, but it will not affect the reliability of power supply. There are many inverter control system which are used at present but there are several problems which is to be solved for better stability of the grid connected system. So, it's very important and researches are being done for grid connected pv generation inverter control system.

In this paper, we also study about the different types of inverter were designed by using MATLAB / SIMULINK and \%THD (Total harmonics distortion) was compared.

\section{References}

[1]. Amirnaser Yazdani, Prajna Paramita Dash. "A control methodology and characterization of dynamics for a photovoltaic(PV) system interfaced with a distribution network,"

[2]. Hiroshi Yamashita, Keita Tamahashi, Masakazu Michihira, Akiara Tsuyoshi, Kuniyuki Amako, Minwon Park. "A novel simulation technique of the PV generation system using real weather conditions,".

[3]. H.S.Bae, SJ.Lee, K.S.Cho, S.SJang. "Current control Design for a Grid Connected Photovoltaic/Fuel Cell DC-AC Inverter".

[4]. O.Wasyneauk, N.AAnwah. "Modeling and Dynamic Performance of a Self-commutated Photovoltaic Inverter System

[5]. Jaydeep Lakwal*, D. M. Deshpande, Arisutha Suresh, Arvind Mittal- Maulana "Cascaded Multilevel Inverter Topologies for Photovoltaic Power Generation Systems" International Journal of ChemTech Research CODEN( USA): IJCRGG ISSN : 0974-4290 Vol.5, No.2, pp 1094-1100, April-June 2013.

[6]. V.Arun, B.Shanthi S.P.Natarajan "Performance Analysis of Multicarrier SPWM Strategies for Three Phase Z-source Seven Level Cascade Inverter" International Journal Of Modern Engineering Research (IJMER) Vol.3, Issue, Jan-Feb 2013. Pp204-211 ISSN 2249-6645.

[7]. Tarak Salmi, Mounir Bouzguenda, Adel Gastli, Ahmed Masmoudi "MATLAB/SIMULINK Based Modelling of Solar Photovoltaic Cell” International Journal of Renewable Energy Research Tarak Salmi et al, Vol:2, No:2, 2012.

[8]. Hyosung Kim and Seung - ki Sul, “ A Novel Filter Design for Output LC Filter of PWM Inverters” Journal of Power Electronics, Vol.11 No.1, January 2011.

[9]. D.M. Brod and D.W. Novotny: “current control of VSI-PWM inverter”, IEEE Trans. Ind. Applications., Vol. IA, My/June 1985. pp. $562-570$

[10]. L.Malesani and P.Tenti. "A Novel hysteresis control method for current-controlled voltage-source PWM inverters with constant modulation frequency", IEEE Transactions on Industrial Electronics, Vol.26, pp.321-325.1998.

[11]. S.Ogasawara, H.Akagi and A.Nabae: "A Novel PWM Scheme of Voltage Source Inverter based on Space Vector Theory". Proceedings of European conference on power ElectronicsApplications, EPE-89, Aachen, Oct.1989, pp.1197-1202. 